\title{
Accessory right hepatic artery branched from gastroduodenal artery
}

\author{
Kohei Yamashita, Daisuke Hashimoto, Rumi Itoyama, Hirohisa Okabe, Akira Chikamoto, Toru Beppu and Hideo Baba*
}

\begin{abstract}
The right hepatic artery usually branches from the common hepatic artery, however, there are cases showing anatomic variations. We present 41 -year-old female patient with gallbladder cancer. In this case, the accessory right hepatic artery branched from the gastroduodenal artery, passed in front of the common bile duct and fed into the anterior segment of the liver. Cholecystectomy and resection of the extrahepatic bile duct with hepaticoenterostomy were performed successfully, preserving the accessory right hepatic artery. There are few reports presenting such an extremely rare anomaly of hepatic arteries in the English literature. Additionally, we herein present a review of the English literature regarding anatomic variations of right hepatic artery.
\end{abstract}

Keywords: Vascular anomaly; Hepatic artery; Gallbladder cancer

\section{Background}

The patterns of the arterial blood supply to the liver have a tendency to show a certain variability $[1,2]$. The right hepatic artery (RHA) usually arises from the common hepatic artery (CHA). One of the best known anatomic variations of hepatic arteries is a replaced or accessory RHA (aRHA) branching from the superior mesenteric artery (SMA) [3, 4]. However, we would like to present an extremely rare case of the aRHA branching from the gastroduodenal artery (GDA).

\section{Case presentation}

A 41-year-old woman was referred to us for gallbladder cancer. An ultrasonography and a contrast-enhanced computed tomography (CT) scan revealed a papillary hypervascular tumor, $25 \times 21 \mathrm{~mm}$, in the gallbladder (Fig. 1a, b). Three-dimensional (3D)-CT angiography showed that the aRHA branched from the GDA, whereas the cholecystic artery could not be detected (Fig. 1c, d). The aRHA passed in front of the common bile duct and fed into the anterior segment of the liver (Fig. 1e). The proper hepatic artery (PHA) was divided distally into the RHA and the middle hepatic artery (MHA). The left hepatic artery (LHA) was replaced on

\footnotetext{
* Correspondence: hdobaba@kumamoto-u.ac.jp
Department of Gastroenterological Surgery, Kumamoto University Graduate
School of Medical Sciences, 1-1-1 Honjo, Chuo-ku, Kumamoto City 860-8556,

* Correspondence: hdobaba@kumamoto-u.ac.jp
Department of Gastroenterological Surgery, Kumamoto University Graduate
School of Medical Sciences, 1-1-1 Honjo, Chuo-ku, Kumamoto City 860-8556,

* Correspondence: hdobaba@kumamoto-u.ac.jp
Department of Gastroenterological Surgery, Kumamoto University Graduate
School of Medical Sciences, 1-1-1 Honjo, Chuo-ku, Kumamoto City 860-8556, Japan
}

tion was not detected in this case.

The patient underwent operation, and laparotomy revealed that there was no invasion into the liver. The aRHA branching from the GDA was detected being consistent with the preoperative 3D-CT (Fig. 2a). The cholecystic artery was found, arising from the aRHA (Fig. 2b). Finally, the cholecystic artery was cut and resection of the gallbladder, and the extrahepatic bile duct with additional hepaticoenterostomy was performed, preserving the aRHA successfully (Fig. 2c). Whereas the effectiveness of lymphadenectomy for early-stage gallbladder cancer has been controversial [5], we performed resection of the extrahepatic bile duct for lymph node dissection. Macroscopically, the tumor was $2.5 \times$ $2.0 \mathrm{~cm}$ (Fig. 2d). Postoperative pathological analysis diagnosed a papillary adenocarcinoma within the mucosal layer of the gallbladder.

Michels et al. published autopsy series about hepatic artery variants in 1966 [6], and in which, they indicated that aRHA uncommonly branches from GDA. We reviewed the English literature, in which 6588 cases were analyzed about anatomic variation of atic artery, including the presented case [3,7-14] (Table 1). This study was approved by the Institutional Review Board of Kumamoto University Hospital. Among 6588 cases, 5696 cases (86.5\%) had standard anatomy. Replaced RHA and aRHA were

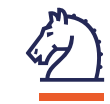




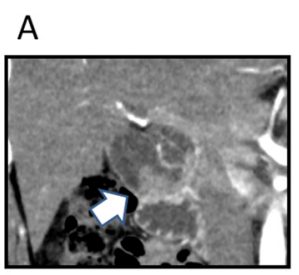

C

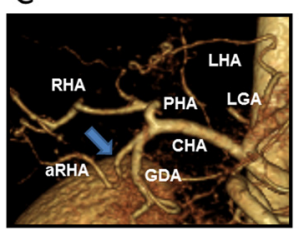

$\mathrm{E}$

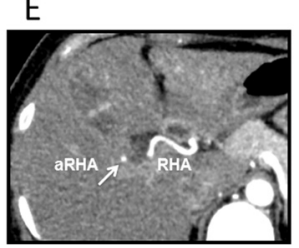

Fig. 1 Preoperative findings. A contrast-enhanced CT (a) and ultrasonography (b) revealed a papillary hypervascular tumor, $25 \times 21 \mathrm{~mm}$, in the gallbladder. The 3D-CT angiography (c, d) indicated that the aRHA (arrow) branched from the GDA, whereas the cholecystic artery could not be detected. The aRHA (arrow) fed into the anterior segment of the liver (e). CHA common hepatic artery, GDA gastroduodenal artery, PHA popper hepatic artery, aRHA accessory right hepatic artery, LGA left gastric artery, LHA left hepatic artery

the most commonly branched from SMA (853 cases, $12.9 \%)$, followed by celiac axis (CA) (16 cases, $0.24 \%$ ), aorta (10 cases, $0.15 \%$ ), and CHA (6 cases, $0.09 \%)$. Two cases had rare anomalies in which replaced RHA branched from LGA or renal artery. In addition, there were three cases $(0.05 \%)$ who had replaced RHA branched from GDA. Hogendorf et al. reported an autopsy case of aRHA branched from GDA [14]. However, to our best knowledge, the presented case is the first

\section{B}

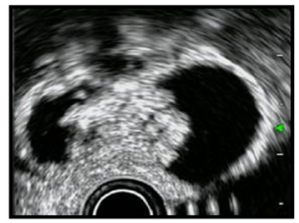

D

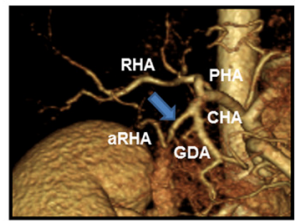

report in which aRHA branched from GDA was detected preoperatively.

\section{Conclusion}

In this case, the successful outcome of the operation was made possible by identifying the aRHA preoperatively. The aRHA should be preserved because it fed the anterior segment of the liver. In addition to the abnormal aRHA, this case had a replaced LHA which the use of the



C

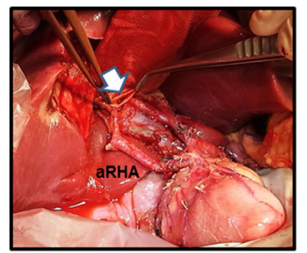

B

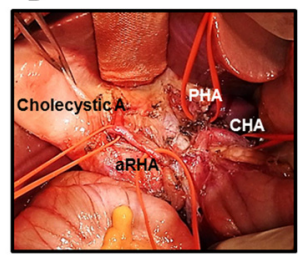

D

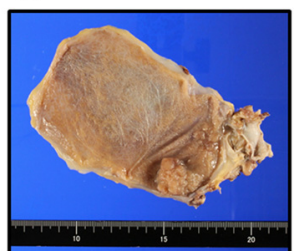

Fig. 2 Operative findings. The aRHA branching from the GDA was detected (a). The cholecystic artery was found, arising from the aRHA (b). The gallbladder and the extrahepatic bile duct were resected, preserving the aRHA (c). Macroscopically, the tumor was $2.5 \times 2.0 \mathrm{~cm}(\mathbf{d})$. CHA common hepatic artery, GDA gastroduodenal artery, PHA popper hepatic artery, aRHA accessory right hepatic artery, LGA left gastric artery, LHA left hepatic artery. Arrow: cut end of the bile duct 
Table 1 Anatomic variations of replaced and accessory right hepatic artery

\begin{tabular}{|c|c|c|c|c|c|c|c|c|c|c|c|c|c|}
\hline \multirow[t]{2}{*}{ Author } & \multirow{2}{*}{$\begin{array}{l}\text { Total } \\
\text { cases } \\
(n)\end{array}$} & \multicolumn{12}{|c|}{ Origin of RHA or accessory RHA (n) } \\
\hline & & $\begin{array}{l}\text { Standard } \\
\text { anatomy }\end{array}$ & $\begin{array}{l}\text { Replaced } \\
\text { RHA from } \\
\text { SMA }\end{array}$ & $\begin{array}{l}\text { Accessory } \\
\text { RHA from } \\
\text { SMA }\end{array}$ & $\begin{array}{l}\text { Replaced } \\
\text { RHA from } \\
\text { CA }\end{array}$ & $\begin{array}{l}\text { Accessory } \\
\text { RHA from } \\
\text { CA }\end{array}$ & $\begin{array}{l}\text { Replaced } \\
\text { RHA from } \\
\text { CHA }\end{array}$ & $\begin{array}{l}\text { Replaced } \\
\text { RHA from } \\
\text { aorta }\end{array}$ & $\begin{array}{l}\text { Accessory } \\
\text { RHA from } \\
\text { aorta }\end{array}$ & $\begin{array}{l}\text { Replaced RHA } \\
\text { from renal } \\
\text { artery }\end{array}$ & $\begin{array}{l}\text { Replaced } \\
\text { RHA from } \\
\text { LGA }\end{array}$ & $\begin{array}{l}\text { Replaced } \\
\text { RHA from } \\
\text { GDA }\end{array}$ & $\begin{array}{l}\text { Accessory } \\
\text { RHA from } \\
\text { GDA }\end{array}$ \\
\hline Hiatt J. [3] & 1000 & 871 & 129 & & 0 & 0 & 0 & 0 & 0 & 0 & 0 & 0 & 0 \\
\hline Covey A. [7] & 600 & 512 & 55 & 33 & 0 & 0 & 0 & 0 & 0 & 0 & 0 & 0 & 0 \\
\hline Gruttadauria S. [11] & 701 & 572 & 110 & & 5 & & 2 & 8 & & 1 & 1 & 2 & 0 \\
\hline Koops A. [8] & 604 & 520 & 60 & 21 & 1 & 1 & 0 & 1 & 0 & 0 & 0 & 0 & 0 \\
\hline Abdullah S. [12] & 932 & 772 & 155 & & 5 & & 0 & 0 & 0 & 0 & 0 & 0 & 0 \\
\hline Lopez-Andujar R. [9] & 1081 & 946 & 118 & 17 & 0 & 0 & 0 & 0 & 0 & 0 & 0 & 0 & 0 \\
\hline Winston C. [13] & 371 & 347 & 15 & 0 & 4 & 0 & 4 & 0 & 0 & 0 & 0 & 1 & 0 \\
\hline Loschner C. [10] & 1297 & 1156 & 103 & 37 & 0 & 0 & 0 & 0 & 1 & 0 & 0 & 0 & 0 \\
\hline Hogendorf P. [14] & 1 & $(-)$ & $(-)$ & $(-)$ & $(-)$ & $(-)$ & $(-)$ & $(-)$ & $(-)$ & $(-)$ & $(-)$ & $(-)$ & 1 \\
\hline This report & 1 & $(-)$ & $(-)$ & $(-)$ & $(-)$ & $(-)$ & $(-)$ & $(-)$ & $(-)$ & $(-)$ & $(-)$ & $(-)$ & 1 \\
\hline Total & 6588 & 5696 & 853 & & 16 & & 6 & 10 & & 1 & 1 & 3 & 2 \\
\hline
\end{tabular}

RHA right hepatic artery, SMA superior mesenteric artery, CA celiac axis, CHA common hepatic artery, LGA left gastric artery, GDA gastroduodenal artery 
preoperative 3D-CT angiography helped to establish beforehand. We believe that this extremely rare arterial pattern should be known by surgeons.

\section{Consent}

Written informed consent was obtained from the patient for publication of this case report and any accompanying images. A copy of the written consent is available for review by the Editor-in-Chief of this journal.

\section{Abbreviations}

aRHA: accessory right hepatic artery; CA: celiac axis; $\mathrm{CHA}$ : common hepatic artery; CT: computed tomography; GDA: gastroduodenal artery; LGA: left gastric artery; LHA: left hepatic artery; MHA: middle hepatic artery;

PHA: proper hepatic artery; SMA: superior mesenteric artery.

\section{Competing interests}

The authors declare that they have no competing interests.

\section{Authors' contributions}

KY carried out the acquisition of data and drafted the manuscript. DH was involved in drafting the manuscript. IR carried out the acquisition of data. $H O, A C, T B$, and $H B$ have given final approval of the version to be published. All authors read and approved the final manuscript.

\section{Acknowledgements}

No funding was received for this study.

Received: 7 May 2015 Accepted: 20 September 2015

Published online: 28 September 2015

\section{References}

1. Panagouli E, Venieratos D, Lolis E, Skandalakis P. Variations in the anatomy of the celiac trunk: a systematic review and clinical implications. Ann Anat. 2013;195:501-11

2. Sebben GA, Rocha SL, Sebben MA, Parussolo Filho PR, Gonçalves BH. Variations of hepatic artery: anatomical study on cadavers. Rev Col Bras Cir. 2013;40:221-6.

3. Hiatt JR, Gabbay J, Busuttil RW. Surgical anatomy of the hepatic arteries in 1000 cases. Ann Surg. 1994;220:50-2.

4. Singh B, Anand M, Gupta S. A rare variant angioarchitecture of upper abdomen. Anat Cell Biol. 2014;47:73-6.

5. Fetzner UK, Hölscher AH, Stippel DL. Regional lymphadenectomy strongly recommended in T1b gallbladder cancer. World J Gastroenterol. 2011;17:4347-8.

6. Michels NA. Newer anatomy of the liver and its variant blood supply and collateral circulation. Am J Surg. 1966;112:337-47.

7. Covey AM, Brody LA, Maluccio MA, Getrajdman GI, Brown KT. Variant hepatic arterial anatomy revisited: digital subtraction angiography performed in 600 patients. Radiology. 2002;224:542-7.

8. Koops A, Wojciechowski B, Broering DC, Adam G, Krupski-Berdien G. Anatomic variations of the hepatic arteries in 604 selective celiac and superior mesenteric angiographies. Surg Radiol Anat. 2004;26:239-44.

9. López-Andújar R, Moya A, Montalvá E, Berenguer M, De Juan M, San Juan F, et al. Lessons learned from anatomic variants of the hepatic artery in 1,081 transplanted livers. Liver Transpl. 2007;13:1401-4.

10. Löschner C, Nagel SN, Kausche S, Teichgräber U. Hepatic arterial supply in 1297 CT-angiographies. Rofo. 2015;187:276-82.

11. Gruttadauria S, Foglieni CS, Doria C, Luca A, Lauro A, Marino IR. The hepatic artery in liver transplantation and surgery: vascular anomalies in 701 cases. Clin Transplant. 2001:15:359-63.

12. Abdullah SS, Mabrut JY, Garbit V, De La Roche E, Olagne E, Rode A, et al. Anatomical variations of the hepatic artery: study of 932 cases in liver transplantation. Surg Radiol Anat. 2006;28:468-73.
13. Winston CB, Lee NA, Jarnagin WR, Teitcher J, DeMatteo RP, Fong $Y$, et al $C T$ angiography for delineation of celiac and superior mesenteric artery variants in patients undergoing hepatobiliary and pancreatic surgery. AJR Am J Roentgenol. 2007;189:W13-9.

14. Hogendorf $P$, Topol M. Variations of the hepatobiliary vasculature including coexistence of accessory right hepatic artery with unusually arising double cystic arteries: case report and literature review. Anat Sci Int. 2014;89:195-8.

\section{Submit your manuscript to a SpringerOpen ${ }^{\odot}$ journal and benefit from:}

- Convenient online submission

- Rigorous peer review

- Immediate publication on acceptance

Open access: articles freely available online

- High visibility within the field

- Retaining the copyright to your article

Submit your next manuscript at $>$ springeropen.com 